\title{
EDITORIAL
}

\section{The Forthcoming World Decade of The Biosphere, 1982-92}

\begin{abstract}
$\mathrm{T}$ here seems no question that, for the lasting preservation of Man's and Nature's environment throughout the world, a new thrust is needed involving all peoples, resources, and their development-everywhere. We ourselves feel that this might best be furthered through global exhortation and ethical publicization of The Biosphere as our home and planetary life-support system, which is nevertheless insecure and even threatened in various ways, and which accordingly needs understanding and fostering. Basically it is jeopardized by ever-increasing human populations and their profligate use of the planet's limited resources. Most of this and much of the following we have said many times before; but we go on repeating it in the hope of ultimately being really heeded and, meanwhile, in support of the action outlined below, following the initial proposal in the opening pages of our Summer issue.

The Biosphere may be defined as the peripheral envelope of the Earth together with its surrounding atmosphere - just as far down and up as, but no farther in either direction than, living things exist quite naturally. It thus ranges from the deepest layers of soils and deposits on ocean floors, unpwards to the highest levels of the atmosphere which contain any form of life -including Man (used collectively as embracing men, women, and children), with his unique intelligence and concomitant capabilities. These last circumstances have enabled Man to evolve in recent millennia and emerge especially in the last few decades as the world's undisputed pandominant. But although it seems clear that Man now has the knowledge and means to save his world, he still lacks sufficient urge and collective selflessness to do so. This is quite painfully obvious for all to see who think!

Rather than await some fantastic ecocalamity of nuclear holocaust, widespread famine, or pandemic disease, such as might finally force the world's residual population to take the necessary steps to save itself and its successors and what remained of Nature for posterity, we feel that preparation should start forthwith for more positive and timely action.

We believe that the widest possible education about The Biosphere, and Man's place in it and utter dependence on it of which he forms an integral part, would be a positive step in the right direction of what needs to be a march for survival. Such a move is being supported by (1) a planned new international journal stressing environmental education, appropriately named The Environmentalist and published by our own fine publishers, (2) a book to elucidate what has gone wrong on a global scale and needs to be put right, followed by (3) a high-level but 'free' conference to discuss, inter alia on the findings of that elucidatory book, what Man needs to do to save his world, and, above all, (4) the launching by the World Environment and Resources Council (WERC) and other appropriate bodies, and henceforth promotion in every possible way, of The World Decade of the Biosphere, 1982-92. Support for this from WERC, and their planned means of promoting it globally with maximum attainable effects, are described in the 'Open Letter', by the principal officers of WERC, which is published directly below.

In a paper recently delivered to the Oxford International Symposium on Environment and the Use of Resources, the means were discussed by which it was considered this Decade might best be furthered, and the hope was expressed that their implementation would lead to a widespread feeling of 'togetherness' among people everywhere as Guardians of the Biosphere - and hence of Man's and Nature's destiny for a lastingly robust future. Subsequently, with the full approval of the organizers of the Oxford Symposium, that paper was revised and given several extra sections for publication as advised in this issue (pp. 271-7).
\end{abstract}

N.P.

\section{OPEN LETTER}

\section{Support for the World Decade of The Biosphere, 1982-92}

$\mathrm{M}$ an is a consumer: he depends on the benevolent though limited production of The Biosphere to satisfy his needs. Such truth is of course well understood by ecologists and many other scientists, but only a very small proportion of the world's citizens know it or, if they do, realize its enormous implications - particularly for themselves.

These disturbing facts have been pointed out with forceful clarity and characteristic leadership in Environmental Conservation - in recent editorials on resources and the Biosphere (Polunin, 1979, 1980a, 1980 b), and in cognate proposals made in collaboration with others writing from different continents (Vallentyne et al., 1980a, 1980b; see also White \& Tolba, 1979). The substance of the emergent main proposal is that, during the ten-years' period of 1982-92, the whole of mankind should not only be made aware of the concept of The Biosphere and familiar with the full meaning of the term, but should also become sensitized to the absolute dependence of Man on that production facility of which he is an integral part. Therefrom should stem due action.

The significance of Man's understanding of his link with the rest of The Biosphere cannot be overstated. In our political societies, be they democratic or state-controlled, there remains an urgent imperative for society ('the man in the street') to recognize the need for, and support plans of, governments to maintain a balanced ecological system in which Man plays a leading role. If society fails to recognize the need for care of the global garden (The Biosphere), our world of Man and Nature will surely change out of all bounds and probably perish. This, however, is not necessary under the stewardship of Man, with his extraordinary capabilities stemming from unique intelligence.

Let us therefore support Drs Vallentyne, Strickler \& Polunin, and applaud them for their initiative in raising The Biosphere to the high profile which it justly deserves-as our global life-support system without which our civilization cannot survive.

The Officers of the World Environment and Resources Council (WERC)* wish to identify themselves and their organization with the World Decade of The Biosphere, and hereby announce that they intend, through their 
programme in the coming years, to promote and foster it in every possible way-with the objective of making everyone aware of The Biosphere, what it is, and how utterly we and all mankind depend upon it. We must therefore guard it everywhere - from the deepest ocean deposits to the highest layers of the atmosphere in which any form of life exists, and on all scales ranging from micro-local to fully global.

Starting now and for the years to come, WERC will promote the concept of The Biosphere in its own and its collaborating journals, especially Environmental Conservation, The Environmentalist (which is to stress environmental education and is planned to start publication through Elsevier Sequoia in the Spring of 1981), Habitat International, and Resources Newsletter. At the same time WERC is confident of obtaining the active support, in promoting and maintaining this quite vital educational initiative, of organizations and individuals practically throughout the world, who in rather numerous instances have already indicated their concerned interest-see, for example, the response to an earlier suggestion from which this larger one grew (Vallentyne, 1980), and also the pungent comments of Cloud (1980).

As well as launching The World Decade of The Biosphere in 1982 (ten years after 'Stockholm'), WERC is proposing to organize, in the same year, an allied international conference on 'Education for the Protection of The Biosphere'. Moreover, a further series of symposia, culminating in a world conference, is being planned to deal with the wise management of biospheral resources; this series is expected to start with consideration of forests, and to continue with river-basin management.

All higher animals are to some extent 'aware', but only Man is aware that he is aware; so let all members of Homo sapiens become truly and acutely aware of our dependence on The Biosphere, and let us understand and foster it in every possible way.

The Council of WERC will be pleased to hear from any organization which may be, or individual who is, willing to help to promote this initiative. WERC will coordinate this support and will endeavour to have a meaningful dialogue with the governments of the world. All communications should be addressed to one of the undersigned:

\section{REFERENCES}

CLOUD, Preston (1980). An International Year of The Biosphere? Environmental Conservation, 7 (2), p. 92.

POLUNIN, Nicholas (as N.P.) (1979). Editorial: Global Resource Strategy. Environmental Conservation, 6 (2), pp. $85-7$.

POLUNIN, Nicholas (as N.P. $(1980 a)$. Editorial: Actions for a New Decade. Environmental Conservation, 7 (1), pp. $1-2$.

POLUNIN, Nicholas (as N.P.) (1980 b). Editorial: Environmental Education and the Biosphere. Environmental Conservation, 7 (2), pp. 89-90.

VALLENTYNE, John R. (1980). Early reactions to the concept of 'The International Year of The Biosphere'. Environmental Conservation, 7 (2), pp. 97-9.

VALLENTYNE, John R., STRICKLER, J. R. \& POLUNIN, Nicholas (1980a). Proposal: International Year of The Biosphere. Environmental Conservation, 7 (1), p. 2.

VALLENTYNE, John R., STRICKLER, J. R. \& POLUNIN, Nicholas (1980b). Battle for The Biosphere. Environmental Conservation, 7 (2), pp. $90-1$

WHITE, Gilbert F.\& TOLBA, Mostafa K. (1979). Statement on global life-support systems. Environmental Conservation, 6 (2), p. 88.

Pierre Laconte, President of WERC

University of Louvain

13 Avenue $G$. Lemaitre

B-1348 Louvain-la-Neuve

Belgium,

Philip H. Jones, Vice-President of WERC

Institute for Environmental Studies

University of Toronto

Toronto

Ontario MSS 1A4, Canada,
$\&$

David Hughes-Evans, Executive Officer of WERC 183 Quadrangle Towers

Cambridge Square

London W2

England (tel. 01402 1009).

*Described in our Summer issue of this year (Environmental Conservation, 7 (2), pp. 91-2, 1980). - Ed.

\section{The Theoretician}

He knows no fact;

He knows but theory.

He does not know

that he is dreary.

The outside world

is big and wide -

to learn from it

is 'neath his pride'.
This ostrich, when

he's thus disposed, leaves his backside so exposed!
Reid A. Bryson, Director

Institute for Environmental Studies University of Wisconsin 1225 West Dayton Street Madison

Wisconsin 53706, USA. 